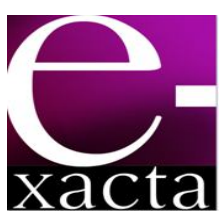

ISSN: 1984-3151

\section{MAPEAMENTO do CONFLito do USO do SOlo EM ÁreAs de Preservação Permanente do MunicíPIO de PIEdade dos Gerais/MG}

\author{
Mapping of the conflict of Soll Use in Areas Of Permanent \\ Preservation on the City of Piedade dos Gerais/MG
}

1 Pós-graduanda em Gestão Ambiental e Geoprocessamento pelo Centro Universitário de Belo Horizonte - UniBH. Graduada em Ecologia UniBH, 2012. Belo Horizonte, MG. camilaemidioribeiro@yahoo.com.br.

2 Doutoranda em Geografia - Modelagem dinâmica da Paisagem aplicada ao Planejamento Urbano, Universidade Federal de Minas Gerais. Mestre em Geografia e Análise Ambiental, UFMG, Brasil, 2010. grazielleanjoo@gmail.com.

Recebido em: 19/02/2013 - Aprovado em: 20/04/2013 - Disponibilizado em: 11/06/2013

RESUMO: As ações antrópicas vêm alterando o ambiente ao longo dos anos de maneira desordenada, explorando os recursos naturais de forma irracional, como se fossem inesgotáveis, sem planejamento prévio adequado que garanta a sustentabilidade não alterando o equilíbrio harmonioso da natureza. Muitos danos foram causados em consequência dessas transformações, fazendo com que a crise ambiental fosse uma das questões mais consideradas na atualidade. Para se efetivar a utilização do solo de maneira consciente, torna-se indispensável o conhecimento dos ambientes e o levantamento do uso do solo como medida de auxílio na tomada de decisões e para se preservar as Áreas de Preservação Permanente, que possuem restrições de uso devido à importância de suas funções ecológicas. Nesse sentido, realizou-se o estudo do mapeamento do uso do solo e das APP's do município de Piedade dos Gerais/MG e, posteriormente, o conflito dos usos existentes dentro dessas APP's, a fim de se detectar prováveis ilegalidades prejudiciais ao ambiente. A análise dos resultados comprovou que na região a agropecuária é a classe de uso mais representativa, abrangendo $66,17 \%$ da utilização total. Dentro das APP's, os resultados são os mesmos: 65,14\% das áreas dessas regiões são destinadas à agropecuária e apenas 20,63\% à vegetação densa. São dados que evidenciam o intenso processo de degradação no local indicando, que podem ocasionar graves consequências socioeconômicas e ambientais. É aconselhável que o poder público faça um programa de recuperação de áreas degradadas, além de elaborar, junto à população, técnicas sustentáveis de uso do solo.

PalAVRAS-Chave: Recursos naturais. Mapeamento. Uso do solo. Áreas de Preservação Permanente. SIG.

ABSTRACT: The human activities are altering the environment over the years in a disorderly manner, exploiting natural resources in an irrational way, as if they were inexhaustible, without adequate prior planning to ensure sustainability without changing the harmonious balance of nature. Much damage has been caused as a result of those changes, causing the environmental crisis was considered one of the most nowadays. To carry out the soil use of consciously, it becomes essential to have knowledge of the environment and soil use survey as a measure to aid in decision making, as well as to preserve the Areas Of Permanent Preservation that have restrictions on use due to its ecological importance have. Accordingly, we carried out the study of soil use mapping and APP's of Piedade dos Gerais/MG city, and then the conflict of uses within these existing APP's in order to detect possible illegal acts harmful to the environment. The results showed that in the region, agriculture is the most representative class of use, covering $66.17 \%$ of total use. Inside the APP's the results are the same: $65.14 \%$ of the areas of these regions are intended for farming and only $20.63 \%$ of dense vegetation. These are statistics that show the intense degradation process in place stating that they may cause serious environmental and socioeconomic consequences. It is advisable that the government make a program of rehabilitation of degraded areas, and develop among the population, sustainable techniques for soil use.

KEYWORDS: Natural resources. Mapping. Soil use. Areas of Permanent Preservation. GIS. 


\section{INTRODUÇÃo}

As ações antrópicas vêm alterando o ambiente ao longo dos anos, principalmente após a Revolução Industrial, de uma maneira desordenada, explorando os recursos naturais de forma irracional, como se fossem inesgotáveis (XAVIER-DA-SILVA; ZAIDAN 2004). O aumento populacional e tecnológico, principalmente no século passado, ocasionou um crescimento desordenado nos centros urbanos e rurais e, consequentemente, a intensificação do uso indiscriminado da terra (SIGNORI et al, 2011).

As atividades humanas têm causado degradação e impactos ambientais negativos significativos, principalmente em relação à urbanização e à transformação de habitats naturais em ambientes para produção de itens do consumo humano (SIGNORI, et al, 2011 apud MATSON et al. 1997). Todas as modificações causadas na natureza alteram o seu equilíbrio, que mesmo não sendo estático, apresenta uma dinâmica harmoniosa em evolução estável e contínua (XAVIER-DA-SILVA; ZAIDAN, 2004).

As modificações e alterações, que não são planejadas adequadamente, ameaçam a capacidade de suporte do planeta provocando danos que podem se tornar irreversíveis e prejudiciais não somente à natureza, mas também ao homem. Entre os danos provocados em consequência dessas transformações, pode-se citar: diminuição da cobertura vegetal por desmatamentos e queimadas feitos de forma indiscriminada; mudanças das condições de umidade (locais e regionais); empobrecimento, salinização e erosão dos solos; mudanças negativas no ciclo de nutrientes; prejuízos à biodiversidade; surgimento de pragas; contaminação do solo e da água por agrotóxicos; desertificação; poluição; surgimento e agravamento de doenças e epidemias ao homem, entre outros (SILVA, 1997).
Desse modo, a questão da crise ambiental é uma das mais consideradas na atualidade. A partir dessa análise, a relevância de se preservar o meio em que se vive e a ideia de que o homem está inserido como parte efetiva do meio ambiente passaram a se fortalecer nos últimos anos. A importância de se utilizar os recursos dos ecossistemas naturais de maneira consciente torna indispensável a aquisição de conhecimento sobre o ambiente e sobre sua ocupação. Um método muito utilizado atualmente para se diagnosticar a ocupação do espaço é através do levantamento do Uso e Ocupação da terra (ou do solo), que, de forma sucinta, é definido como a forma pela qual o espaço é ocupado pelo homem (BARBOSA; ANDRADE; ALMEIDA, 2006 apud PACHÊCO; RIBAS, 1998).

O levantamento do Uso do Solo torna-se fundamental e é de grande utilidade para o conhecimento atualizado das formas e padrões de uso e de ocupação do espaço, constituindo importante ferramenta de auxílio ao planejamento de políticas públicas e ambientais e de orientação à tomada de decisão (IBGE, 2006). Nesse sentido, pode-se verificar a melhor forma de se utilizar o solo de uma determinada região (BRITO; PRUDENTE, 2005), fornecendo subsídios para controlar a ocupação humana desorganizada e buscando alternativas que promovam a sustentabilidade através do uso racional da terra e dos recursos.

A partir desse levantamento, é possível se fazer o planejamento do uso do solo, que é o conjunto de técnicas e políticas que, aplicadas corretamente, protegem-no, prolongando o seu potencial produtivo e protegendo suas características naturais. O manejo adequado do solo evita a erosão, que é capaz de afetar e danificar as condições intrínsecas da área como a geologia, a geomorfologia, o regime hidrológico das bacias hidrográficas, podendo até refletir-se no clima local (SILVA, 1997). 
Existem áreas em que $o$ levantamento $e$ monitoramento devem ser constantes, assim como as chamadas Áreas de Preservação Permanente (APP's), a fim de avaliar a integridade e se há algum conflito de uso não permitido. A cobertura vegetal nessas regiões é essencial, pois protege o ambiente natural atenuando os efeitos erosivos e a lixiviação dos solos, contribuindo para a regularização do fluxo hídrico, redução do assoreamento dos cursos d'água e reservatórios, trazendo benefícios para a fauna (COSTA; SOUZA; BRITES, 1996).

Sendo assim, esses locais não são apropriados a sofrerem alterações pelo o uso da terra, devendo estar cobertos com a vegetação original, não podendo, portanto, haver a retirada da cobertura vegetal, permitindo que possam exercer, em plenitude, suas funções ambientais (RIBEIRO et al, 2005).

Para conseguir essa visão do Uso do Solo e das Áreas de Preservação Permanente, o emprego de imagens e dados coletados por sistemas de sensores orbitais tem apresentado grande eficiência e constitui-se em uma ferramenta muito importante para o auxílio na obtenção de informações de grandes áreas na superfície terrestre (DAINESE, 2001). Esta técnica de aquisição de imagens é chamada de Sensoriamento Remoto, que foi definida por Florenzano:

Sensoriamento Remoto é a tecnologia que permite obter imagens e outros tipos de dados, da superfície terrestre, através da captação de/do registro da energia refletida ou emitida pela superfície (FLORENZANO, 2002).

Essas imagens são feitas por sensores instalados em Satélites Artificiais. E através dessas informações, faz-se possível o planejamento adequado de sua utilização.

Até recentemente, a coleta de informações sobre o espaço geográfico era feita apenas em documentos e mapas de papel (CASTRO JúNIOR, [2011?]). Com o desenvolvimento da informática e a evolução de novas tecnologias, tornou-se possível a representação da natureza no ambiente computacional, cada vez de forma mais eficiente (CÂMARA; MEDEIROS, 2001). A partir desse desenvolvimento, surgiu então o geoprocessamento, que é o conjunto de tecnologias voltadas à coleta $e$ tratamento de informações desse espaço geográfico para um objetivo específico (CASTRO JUNIOR, [2011?] apud RODRIGUES, 1993). As ferramentas computacionais para o geoprocessamento são chamadas de Sistemas de Informações Geográficas (SIG) (CASTRO JUNIOR, [2011?]; DAINESE, 2001).

Portanto, a partir da obtenção de imagens da superfície, feita através do Sensoriamento Remoto, e posteriormente, o tratamento e interpretação dessas imagens utilizando-se de tecnologias da informática (Geoprocessamento) com ferramentas computacionais (SIG), é possível originar mapas de representação da Terra. Dessa maneira, pode-se obter informações mais eficientes possíveis do Uso do Solo, geologia, relevo, hidrográfica, cobertura vegetal, Áreas de Preservação Permanente, entre outros, do espaço geográfico estudado (IBGE, 2006). Esses mapas podem ser utilizados para 0 diagnóstico ambiental e, através dessas informações, faz-se possível o planejamento de políticas públicas das cidades, culminando no uso adequado espaço.

O objetivo geral desta pesquisa é identificar a distribuição do Uso do Solo em Piedade dos Gerais, Minas Gerais (MG), analisando quais transformações no espaço geográfico põem em risco a integridade das Áreas de Preservação Permanente.

Os objetivos específicos são:

- Descrever o Município de Piedade dos Gerais através da caracterização histórica, socioeconômica e ambiental; 
- Elaborar o mapeamento das Áreas de Preservação Permanente (APP's) no município;

- Elaborar o estudo do Uso e Ocupação do Solo em Piedade dos Gerais;

- Confrontar o Uso do Solo atual com as APP's existentes.

O município de Piedade dos Gerais/MG foi escolhido em função de raízes familiares e motivos pessoais das autoras, e a pesquisa se justifica pela falta de estrutura e assistência técnica em relação às políticas ambientais do município. A falta de estudo mais aprofundado acarretou uma transformação desordenada do espaço. Vê-se então a importância de se diagnosticar a paisagem do município, levantando o Uso da Terra para um posterior planejamento eficaz e adequado sem que haja interferência nas Áreas de Preservação Permanente.

\section{MATERIAL E MÉTOdOS}

O trabalho aqui apresentado foi realizado em 05 etapas:

- Estudo sobre a caracterização histórica do município, desde sua fundação até sua emancipação;

- Estudo do município de acordo com suas características ambientais, sociais e econômicas;

- Elaboração dos mapas de Uso e Ocupação da Terra de Piedade dos Gerais/MG, referente ao ano de 2010 através do software ArcGis 9.3;

- Mapeamento das Áreas de Preservação Permanente (APP's) segundo metodologia proposta por Peluzio, Santos e Fielder (2010), no software ArcGis 9.3;

- Confronto do Uso da Terra atual com as APP's existentes, no software ArcGis 9.3.
Para o estudo da história de Piedade dos Gerais/MG, utilizou-se como referências dados do Instituto Brasileiro de Geografia e Estatística (IBGE) Cidades@e informações do livro “Piedade... o recanto das Gerais" de Assis (2001).

Para a elaboração das características socioeconômicas, utilizou-se de dados atuais do Censo 2010, e para o mapeamento da área urbana e área rural utilizou-se de bases cartográficas disponíveis no site IBGE.

As características ambientais foram descritas com base no Plano de Caracterização da Área De Proteção Ambiental Vale Do Rio Macaúbas (MARQUES, 2011) e através de bases de dados do IBGE.

O mapeamento da hidrologia, declividade e hipsometria foi feito com o banco de dados obtido do Geominas e IBGE e serviram como base para a elaboração do mapa de APP's do município com o auxílio do tutorial, para a delimitação dessas áreas, elaborado e organizado por Peluzio, Santos e Fielder (2010).

Para a elaboração do mapa de Uso e Ocupação do Solo, utilizou-se de um mosaico de 3 Imagens do satélite de média resolução $(5 \mathrm{~m})$ RapidEye (datadas de 14 de junho de 2010; 16 de junho de 2010; 20 de julho de 2010) e obtidas na Gerência de Monitoramento da Vegetação e da Biodiversidade do Instituto Estadual de Florestas de Minas Gerais (GMVBio - IEF).

O método de mapeamento do Uso e Ocupação do Solo foi feito através da técnica de Classificação Supervisionada, que consiste em extrair manualmente amostras de pixel para auxiliar o software, ArcGis 9.3, a interpretar a imagem de forma automática proporcionando uma classificação mais apurada. As etapas para a confecção dos mapas foram: 
- Composição colorida RGB: banda 3 B; banda 4 G; banda $5 \mathrm{R}$ das 3 imagens RapidEye, que juntas abrangem todo o município de estudo;

- Equalização das 3 imagens a fim de, segundo Carvalho (2010), igualar os tons de cinza dos mesmos objetos de cada imagem para que não haja interferência da classificação posteriormente;

- Coleta das amostras para cada uma das 3 imagens através da criação de polígonos diferentes para cada classe de uso do solo, em que são inseridas na tabela de atributos;

- Processamento das imagens com as amostras coletadas e as classes definidas;

- Recorte das imagens já processadas nos limites do município;

- Transformação das imagens processadas de RASTER (.tif) para SHAPE (.shp);

- Junção dos 3 polígonos de uso do solo, uma para cada imagem, criados em um polígono apenas;

- Cálculo, na tabela de atributos, dos valores das áreas e porcentagens em relação à área total para cada uma das classes de uso do solo existentes;

- Composição do layout.

Para o confronto entre as APP's e os diferentes tipos de uso do solo, através dos mapas de uso da terra e de APP's elaborados, utilizou-se também o tutorial de Peluzio, Santos e Fielder (2010), onde se recortam as classes de usos do solo existentes dentro das APP's e calculam-se as áreas e porcentagens.

\section{Caracterização do MunicípIo de Piedade DOS GERAIS/MG}

\subsection{LOCALIZAÇÃO}

A área de estudo, município de Piedade dos Gerais, localiza-se na mesorregião Metropolitana de Belo Horizonte e na microrregião de Itaguara. Seus municípios limítrofes são Bonfim, Belo Vale, Jeceaba, Crucilândia, Piracema e Desterro de Entre Rios (Figura 1).

Distancia-se da capital mineira em $125 \mathrm{~km}$, de Brasília em $840 \mathrm{~km}$, do Rio de Janeiro em 550km, de São Paulo em 540km e de Vitória em 655km.

Segundo Assis (2001), Piedade dos Gerais possui, em sua composição, 17 povoados. São eles: Andrade, Alegria, Borges, Campo Redondo, Casa Branca, Caxambu, Contendas, Egito, Godinho, Medeiros, Lagoa, Pamplona, Passa Sete, Retiro, Samambaia dos Padres, Sítio Novo e Vira Sol. 


\section{Localização do Município de Piedade dos Gerais/MG e entorno}

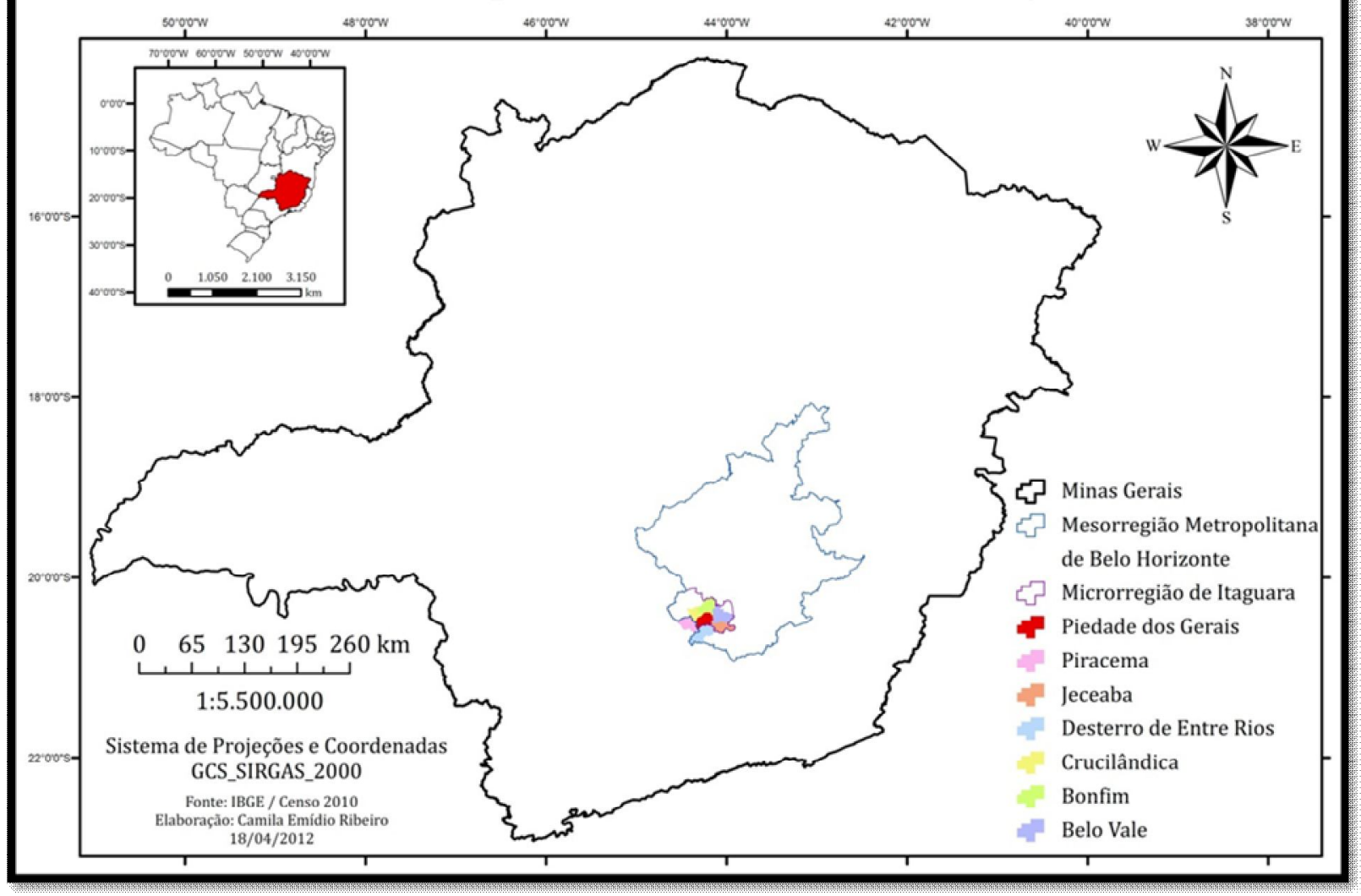

Figura 1 - Mapa de localização do município de Piedade dos Gerais/MG.

\subsection{CARACTERIZAÇÃo hiStÓRICA}

Historicamente, o município tem suas origens na época colonial. No início da colonização do Brasil pelos portugueses, a exploração era feita apenas no litoral. Porém, com a necessidade de dominação de novas terras, os colonizadores estenderam suas buscas por minas de ouro pelo interior do país.

As primeiras expedições pelo estado de Minas Gerais foram comandadas pelo bandeirante Fernão Dias Paes Leme. Posteriormente, o comando passou ao seu genro, também bandeirante, Manuel de Borba Gato, que, em 1710, recebeu uma sesmaria onde o território hoje conhecido por Piedade dos Gerais estava inserido, porém não conhecido (ASSIS, 2001).
Derrotados na Guerra dos Emboabas, alguns desbravadores paulistas iniciaram colonização por toda região sudoeste de Belo Horizonte, passando pelos vales dos Rios Paraopeba e Pará até a desembocadura no Rio São Francisco. Entre eles, estava um português, Francisco Sobreira, que tomou posse de todas essas terras, fixando residência no lugar denominado na época de "Santana do Paraopeba", que hoje é distrito de Belo Vale.

Sobreira ordenou que nos arredores da província fossem erguidas capelas, onde, a partir destas, foram surgindo os povoados que receberam denominações dos santos de sua devoção. Um desses povoados foi Nossa Senhora da Piedade dos Gerais. Não se pode afirmar a data exata da sua fundação, mas indícios mostram que pode ter sido fundada antes de 1754, pois nessa data o Bispo D. 
Frei Manoel da Cruz concedeu a construção de um novo templo em substituição ao já existente e precário. (ASSIS, 2001) (IBGE CIDADES@, 2010).

O povoado de Nossa Senhora da Piedade dos Gerais, em 03 de abril de 1840, foi desmembrado da Paróquia de Nosso Senhor do Bonfim e elevado à Paróquia pela Lei Canônica no 184 , passando a ser um distrito do município de Bonfim.

A simplificação oficial do então distrito de Nossa Senhora da Piedade dos Gerais para apenas Piedade dos Gerais aconteceu em 25 de julho de 1923.

Piedade dos Gerais foi emancipada do município de Bonfim e elevada a município em 30 de dezembro de 1962, através da lei no 2.764. A partir desta data, a cidade passou a administrar suas terras e, em 1964, os piedadenses começaram a eleger as autoridades do Executivo e Legislativo (ASSIS, 2001) (IBGE CIDADES, 2010).

\subsection{Caracterização Socioeconômica}

Através dos dados preliminares do Censo 2010 (IBGE), disponíveis em IBGE Cidades@, realizou-se a caracterização socioeconômica de Piedade dos Gerais.

O Produto Interno Bruto (PIB) de Piedade dos Gerais, segundo IBGE, tem como influência maior o setor de serviços $(60,30 \%)$, seguido do setor agropecuário $(30,15 \%)$ e do setor industrial $(9,55 \%)$. Uma realidade que se difere da realidade brasileira e mineira, na qual o setor de serviços oferece maior influência no PIB, porém seguido do setor industrial e, posteriormente e por último, do setor agropecuário.
O município, predominantemente rural, possui uma área de 259,638 km², sendo dividida em: 2,33\% de área urbana e 97,67\% de área rural (Figura 2). Apesar disso, a diferença populacional entre as duas regiões não é muito acentuada, o que, consequentemente, faz haver uma densidade populacional muito maior na região urbana. $\mathrm{Da}$ população total de 4.640 pessoas $\left(17,87 \mathrm{hab} / \mathrm{km}^{2}\right)$, $2.122(45,7 \%)$ estão na área urbana $(350,77$ $\left.\mathrm{hab} / \mathrm{km}^{2}\right)$ e 2.518 (54,3\%) em área rural $(9,93$ $\left.\mathrm{hab} / \mathrm{km}^{2}\right)$. O total de endereços urbanos existentes é de 1.209 e o total de endereços rurais é de 1.539 (IBGE, Censo 2010).

Economicamente, o município de Piedade dos Gerais apresentou como orçamento os valores apresentados na Tabela 1 a seguir, para os anos 2005, 2006, 2008 e 2009.

Tabela 1

Finanças públicas do município de Piedade dos Gerais/MG dos anos 2005, 2006, 2008 e 2009, relacionando as receitas e as despesas.

\begin{tabular}{|c|c|c|}
\hline \multicolumn{3}{|c|}{$\begin{array}{c}\text { - Finanças Públicas - } \\
\text { Município de Piedade dos Gerais }\end{array}$} \\
\hline Ano & $\begin{array}{c}\text { Receitas } \\
\text { orçamentárias }\end{array}$ & $\begin{array}{c}\text { Despesas } \\
\text { orçamentárias }\end{array}$ \\
\hline 2005 & $\mathrm{R} \$ 4.928 .227,00$ & $\mathrm{R} \$ 4.090 .918,00$ \\
\hline 2006 & $\mathrm{R} \$ 5.684 .214,62$ & $\mathrm{R} \$ 4.935 .020,58$ \\
\hline 2008 & $\mathrm{R} \$ 7.897 .157,40$ & $\mathrm{R} \$ 6.155 .566,54$ \\
\hline 2009 & $\mathrm{R} \$ 7.522 .531,12$ & $\mathrm{R} \$ 6.915 .143,42$ \\
\hline \multicolumn{2}{|c|}{ Fonte: IBGE Cidades@ - Censo 2010 }
\end{tabular}

O valor do rendimento nominal médio mensal por domicílio urbano é de $\mathrm{R} \$ 1.436,38$ e por domicílio rural é de $R \$ 1.298,48$. 


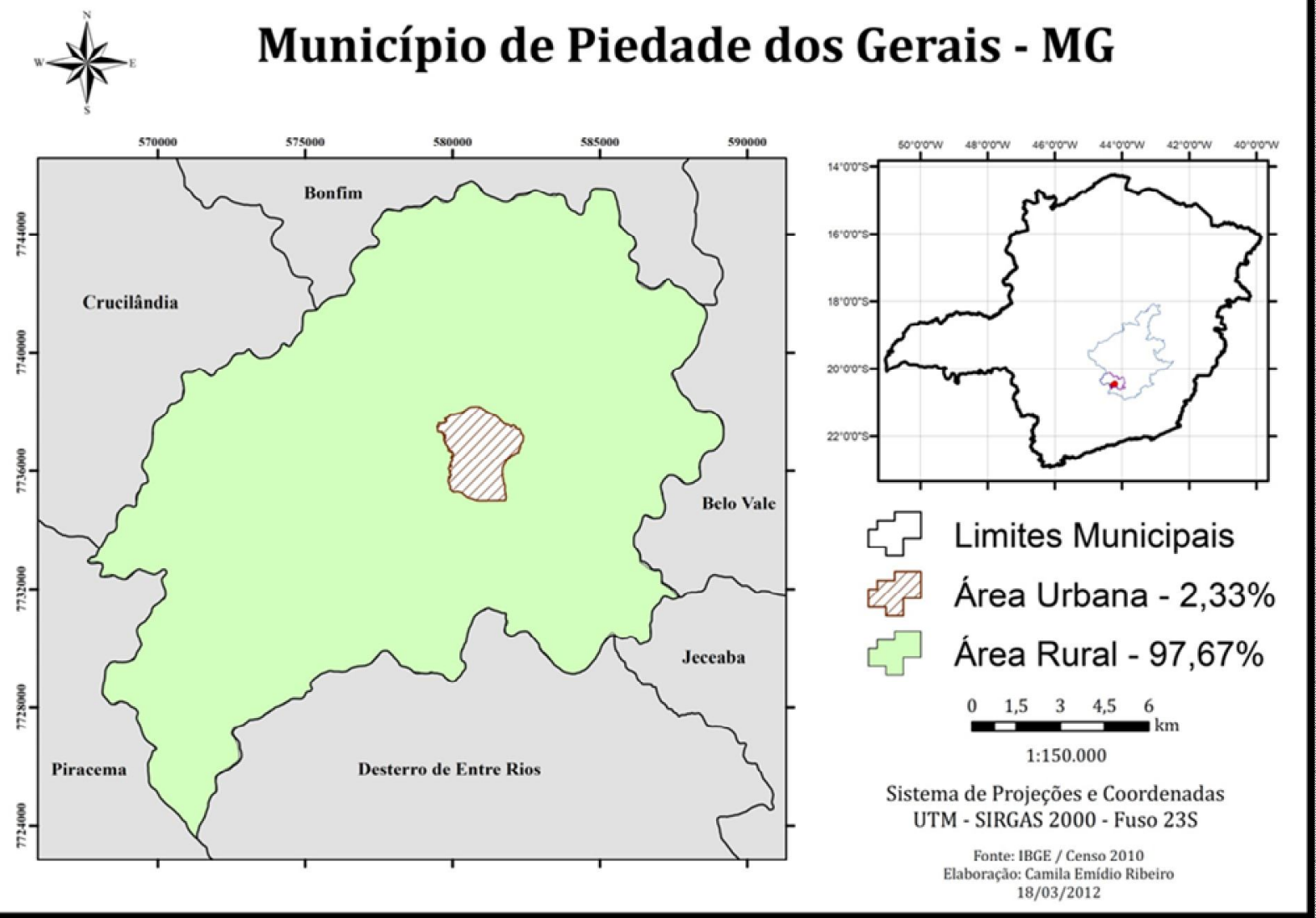

Figura 2 - Município de Piedade dos Gerais e sua divisão entre Área Urbana e Área Rural.

Existem 93 empresas locais atuantes, 4 estabelecimentos de saúde no total e 6 estabelecimentos de ensino. A Taxa de Analfabetismo é apresentada na Tabela 2 a seguir.

Tabela 2

Taxa de Analfabetismo no município de Piedade dos Gerais/MG e sua evolução comparando-se anos de 2000 e 2010.

\begin{tabular}{|l|c|c|}
\hline \multicolumn{3}{|c|}{ Taxa de Analfabetismo } \\
\hline \multicolumn{1}{|c|}{ Faixa Etária } & $\mathbf{2 0 0 0}$ & $\mathbf{2 0 1 0}$ \\
\hline 15 a 24 anos & $5,1 \%$ & $2,4 \%$ \\
\hline 25 a 59 anos & $17,6 \%$ & $11,3 \%$ \\
\hline 60 anos ou mais & $50,1 \%$ & $36,5 \%$ \\
\hline Total - 15 anos ou mais & $19,9 \%$ & $14,7 \%$ \\
\hline
\end{tabular}

Fonte: IBGE Cidades@ - Censo 2010
Segundo o Censo Agropecuário de 2006, os tipos de utilização da terra ocorrem de acordo com a Tabela 3 abaixo:

\section{Tabela 3}

Utilização das terras no município de Piedade dos Gerais/MG.

\begin{tabular}{|c|c|c|}
\hline \multicolumn{3}{|c|}{ Utilização das Terras } \\
\hline Uso & Área $\left(\mathrm{km}^{2}\right)$ & $\%$ \\
\hline Lavouras permanentes & 3,29 & 3,31 \\
\hline Lavouras temporárias & 10,28 & 10,35 \\
\hline $\begin{array}{l}\text { Lavouras - área plantada com } \\
\text { forrageiras para corte }\end{array}$ & 4,75 & 4,78 \\
\hline Pastagens naturais & 27,23 & 27,40 \\
\hline $\begin{array}{l}\text { Pastagens plantadas } \\
\text { degradadas }\end{array}$ & 8,06 & 8,11 \\
\hline $\begin{array}{l}\text { Pastagens plantadas em boas } \\
\text { condições }\end{array}$ & 25,72 & 25,88 \\
\hline APP's e Reserva Legal & 8,70 & 8,76 \\
\hline Matas e/ou florestas naturais & 3,14 & 3,16 \\
\hline
\end{tabular}




\begin{tabular}{|l|r|c|}
\hline Florestas plantadas & 3,54 & 3,56 \\
\hline $\begin{array}{l}\text { Sistemas Agroflorestais - área } \\
\text { cultivada com espécies } \\
\text { florestais, também usada para } \\
\text { lavouras e pastejo. }\end{array}$ & 0,30 & 0,30 \\
\hline Aquicultura & 0,54 & 0,54 \\
\hline $\begin{array}{l}\text { Terras degradadas (erodidas, } \\
\text { desertificadas, salinizadas e } \\
\text { etc.). }\end{array}$ & 0,29 & 0,29 \\
\hline $\begin{array}{l}\text { Terras inaproveitáveis para } \\
\text { agricultura ou pecuária } \\
\text { (pântanos, areais, pedreiras, } \\
\text { etc.). }\end{array}$ & 1,22 & 1,23 \\
\hline $\begin{array}{l}\text { Construções, benfeitorias ou } \\
\text { caminhos. }\end{array}$ & 2,31 & 2,32 \\
\hline
\end{tabular}

Fonte: Censo Agropecuário 2006

\subsection{CaracterizaçÃo Ambiental}

Conforme dados do IBGE, o município está inserido no Bioma Mata Atlântica, fitofisionomia Floresta Estacional Semi-decidual Montana, contudo pode-se encontrar áreas de transição para o Bioma Cerrado, com a presença de espécies típicas.

De acordo com Marques (2011), o clima é do tipo tropical de altitude, com verões chuvosos e invernos secos.

A temperatura média anual gira em torno de $20^{\circ} \mathrm{C}$, sendo que no inverno as noites são bem frias, com temperaturas próximas de $0^{\circ}$, oscilando em até $15^{\circ}$ C no dia. No verão as temperaturas podem ultrapassar os $30^{\circ} \mathrm{C}$ (MARQUES, 2011).

O índice pluviométrico anual, segundo IBGE, está entre 1200 a $1500 \mathrm{~mm}$. O relevo é 10\% plano, 50\% ondulado e $40 \%$ montanhoso.

A sua litologia é representada por rochas gnáissicas de origem magmática e/ou sedimentar de médio grau metamórfico e de rochas graníticas desenvolvidas durante o tectonismo, provenientes do período Paleoproterozoico (IBGE - Geociências).

Os solos são, predominantemente, Latossolos vermelho-amarelo e, em menor representatividade, cambissolos háplicos. (IBGE - Geociências)

A localidade está inserida na Região Hidrográfica do São Francisco, na sub-bacia do Paraopeba e seu principal rio é o Macaúbas (IBGE Geociências).

No município, está inserida a Área de Proteção Ambiental Municipal Vale do Rio Macaúbas (Figura 3), criada pela Lei №564/2002 de 15 de abril de 2002 e regida através da Lei $\mathrm{N}^{\circ} 721 / 2011$ de 26 de abril de 2011, que estabelece Zoneamento Ambiental Ecológico-Econômico para a Área de Preservação Ambiental (APAM) limitando e restrigindo os usos para que não haja degradação.

O Sistema Nacional de Unidades de Conservação da Natureza (SNUC), instituído pela Lei № 9.985, de 18 de julho de 2000, define uma Área de Proteção Ambiental (APA) em seu Art. 15:

A Área de Proteção Ambiental é uma área em geral extensa, com um certo grau de ocupação humana, dotada de atributos abióticos, bióticos, estéticos ou culturais especialmente importantes para a qualidade de vida e o bem-estar das populações humanas, e tem como objetivos básicos proteger a diversidade biológica, disciplinar o processo de ocupação e assegurar a sustentabilidade do uso dos recursos naturais. (SNUC, 2000) 


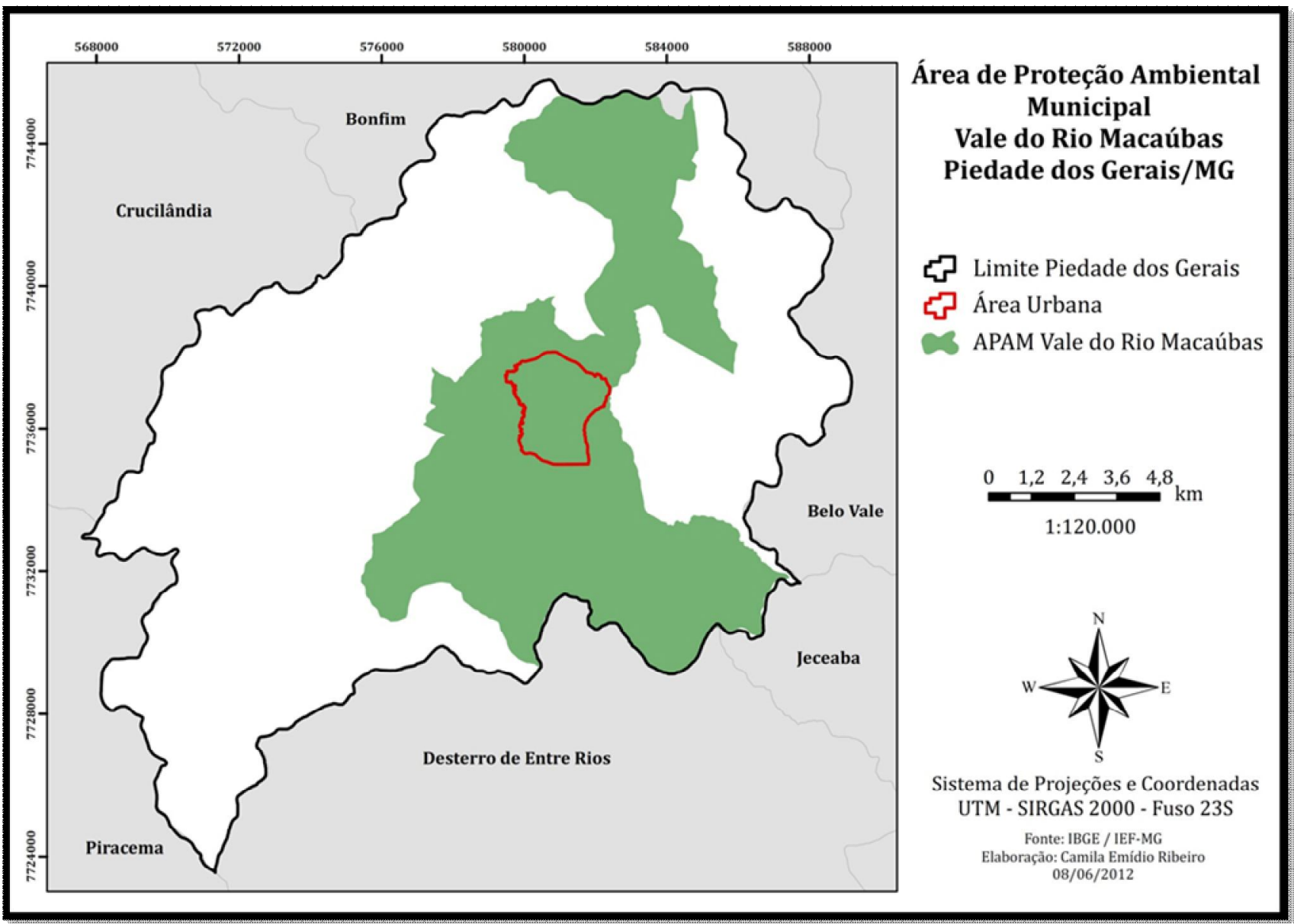

Figura 3 - Área de Proteção Ambiental Municipal Vale do Rio Macaúbas no município de Piedade dos Gerais/MG.

\section{Mapeamento das Áreas de Preservação Permanente (APP's)}

Com o objetivo de disciplinar e limitar as interferências antrópicas sobre o meio ambiente, o artigo $2^{\circ}$ do Código Florestal Brasileiro (Lei 4.771, de 15 de setembro de 1965, revogado pela Lei № 12.651, de 25 de maio de 2012) contempla a criação dessas áreas, as Áreas de Preservação Permanente (APP). Em 20 de março de 2002, a Resolução 303, do Conselho Nacional do Meio Ambiente CONAMA, é criada e "Dispõe sobre parâmetros, definições e limites de Áreas de Preservação Permanente". Em Minas Gerais, há uma Lei Estadual que "Dispõe sobre as Políticas Florestal e de Proteção à Biodiversidade no Estado de Minas Gerais", em que se faz referência às APP's, suas delimitações e funções - Lei ํㅜ 14.309, de 19 de junho de 2002.

De acordo com a Lei Estadual oㅜ 14.309, de 19 de junho de 2002, na Seção II, Art. 10:

\begin{abstract}
Considera-se área de preservação permanente aquela protegida nos termos desta lei, revestida ou não com cobertura vegetal, com a função ambiental de preservar os recursos hídricos, a paisagem, a estabilidade geológica, a biodiversidade, o fluxo gênico de fauna e flora, de proteger o solo e de assegurar o bem-estar das populações humanas.
\end{abstract}

Ainda conforme a Lei citada e em relação às APP's utilizadas no presente estudo, as Áreas de Preservação Permanente situam-se:

II - ao longo dos rios ou de qualquer curso d'água, a partir do leito maior sazonal, medido horizontalmente, cuja largura mínima, em 
cada margem, seja de 30m (trinta metros), para curso d'água com largura inferior a $10 \mathrm{~m}$ (dez metros);

IV - em nascente, ainda que intermitente, qualquer que seja a sua situação topográfica, num raio mínimo de $50 \mathrm{~m}$ (cinquenta metros);

$\mathrm{V}$ - no topo de morro, monte ou montanha, em área delimitada a partir da curva de nível correspondente a dois terços da altura da elevação em relação à base;

VI - em encosta ou parte dela, com declividade igual ou superior a cem por cento ou $45^{\circ}$ (quarenta e cinco graus) na sua linha de maior declive, podendo ser inferior a esse parâmetro a critério técnico do órgão competente, tendo em vista as características edáficas da região.

Para a realização do mapeamento de APP's (Figura 4) do município, primeiramente elaborou-se os mapas de hidrografia (Figura 5), declividade (Figura 6) e hipsometria (Figura 7), estes dois últimos com base nas curvas de nível.
Devido ao fato de a declividade da região não alcançar os $100 \%\left(45^{\circ}\right)$ e de o Geominas não dispor de bases de nascentes, foram mapeadas apenas as APP's de cursos d'água e de topos de morro.

A área total das Áreas de Preservação Permanente de cursos d'água e topo de morro é 106,30 km². O resultado da proporcionalidade de cada APP é:

\section{- APP's Cursos D’água:}

- área: 37,42 km²;

- \% em relação à área total APP's: 35,48;

- \% em relação à área do município: 14,53.

- APP's Topos de Morro:

- área: 68,58 km²;

- \% em relação à área total APP's: 64,52;

- \% em relação à área do município: 26,41.

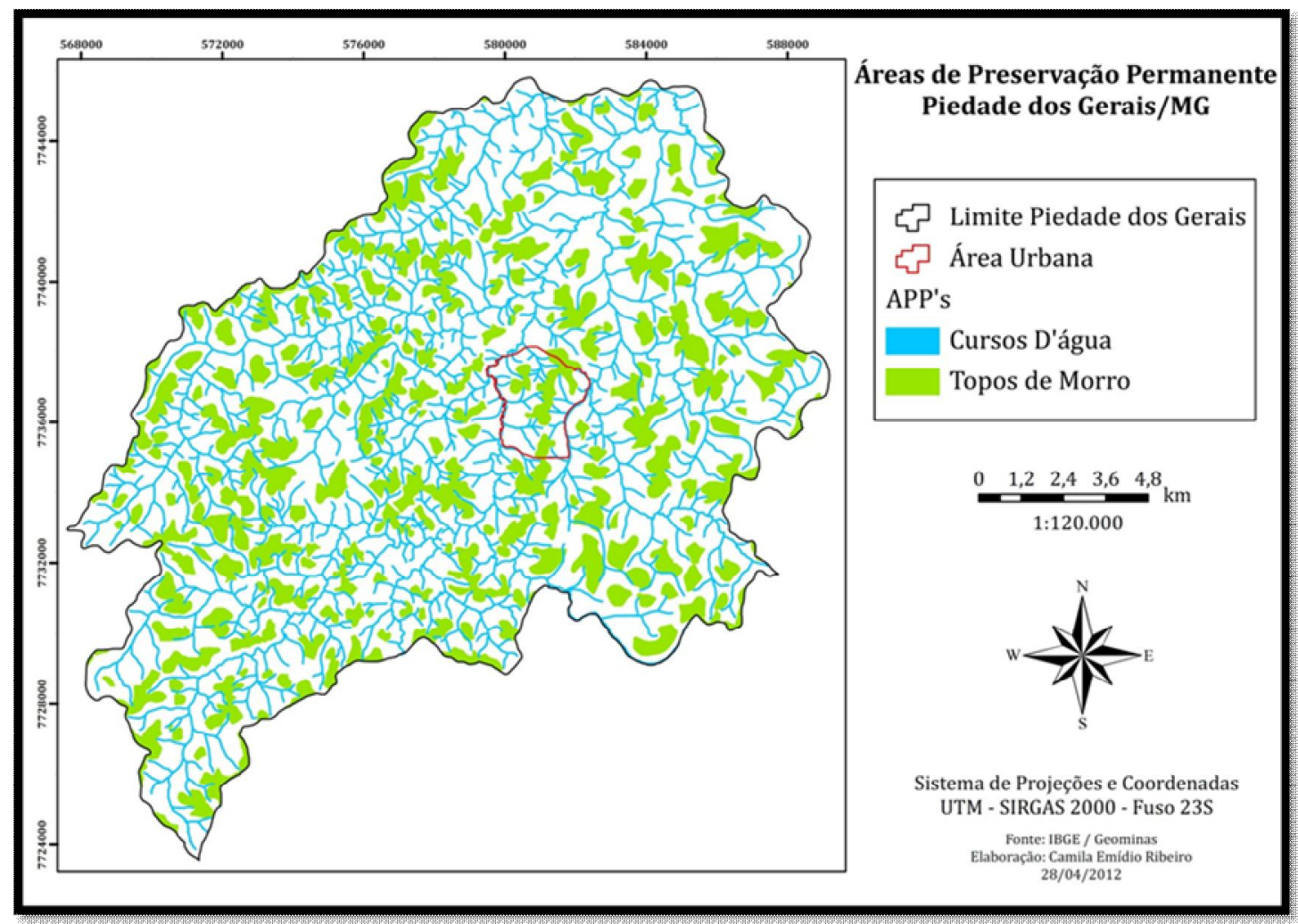

Figura 4 - Mapa das Áreas de Preservação Permanente do município de Piedade dos Gerais/MG. 


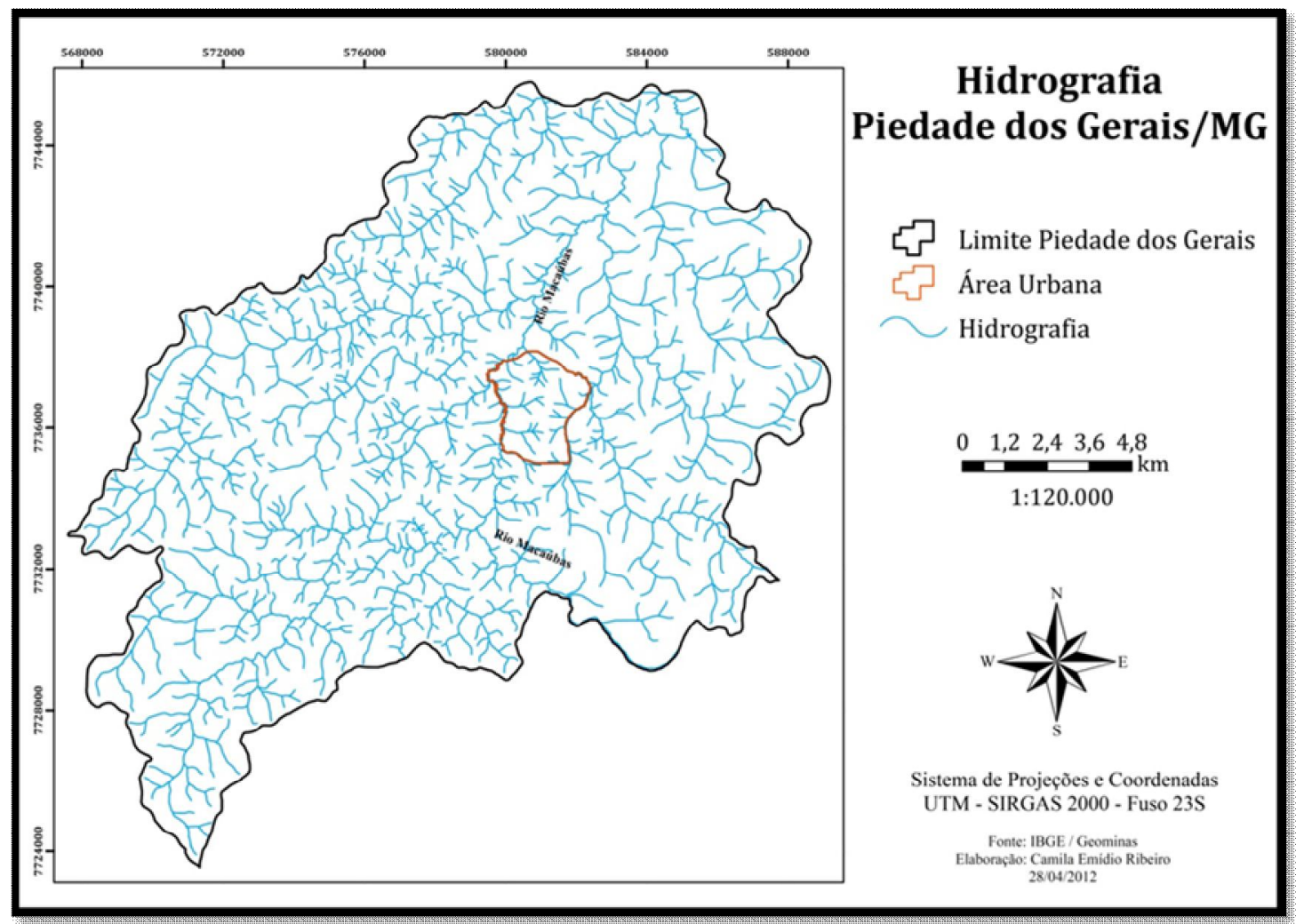

Figura 5 - Mapa de hidrografia do município de Piedade dos Gerais/MG.

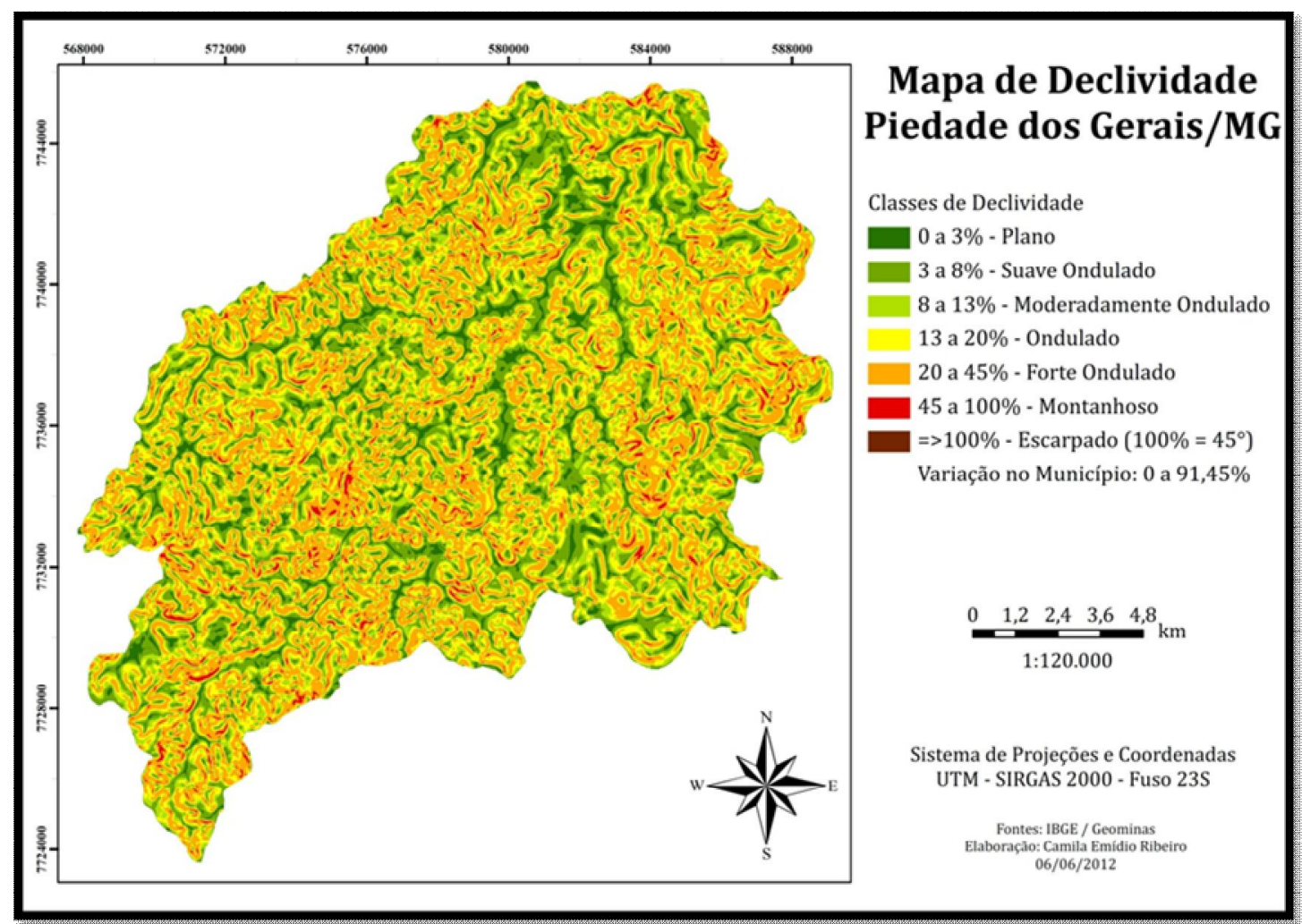

Figura 6 - Mapa de declividade do município de Piedade dos Gerais/MG. 


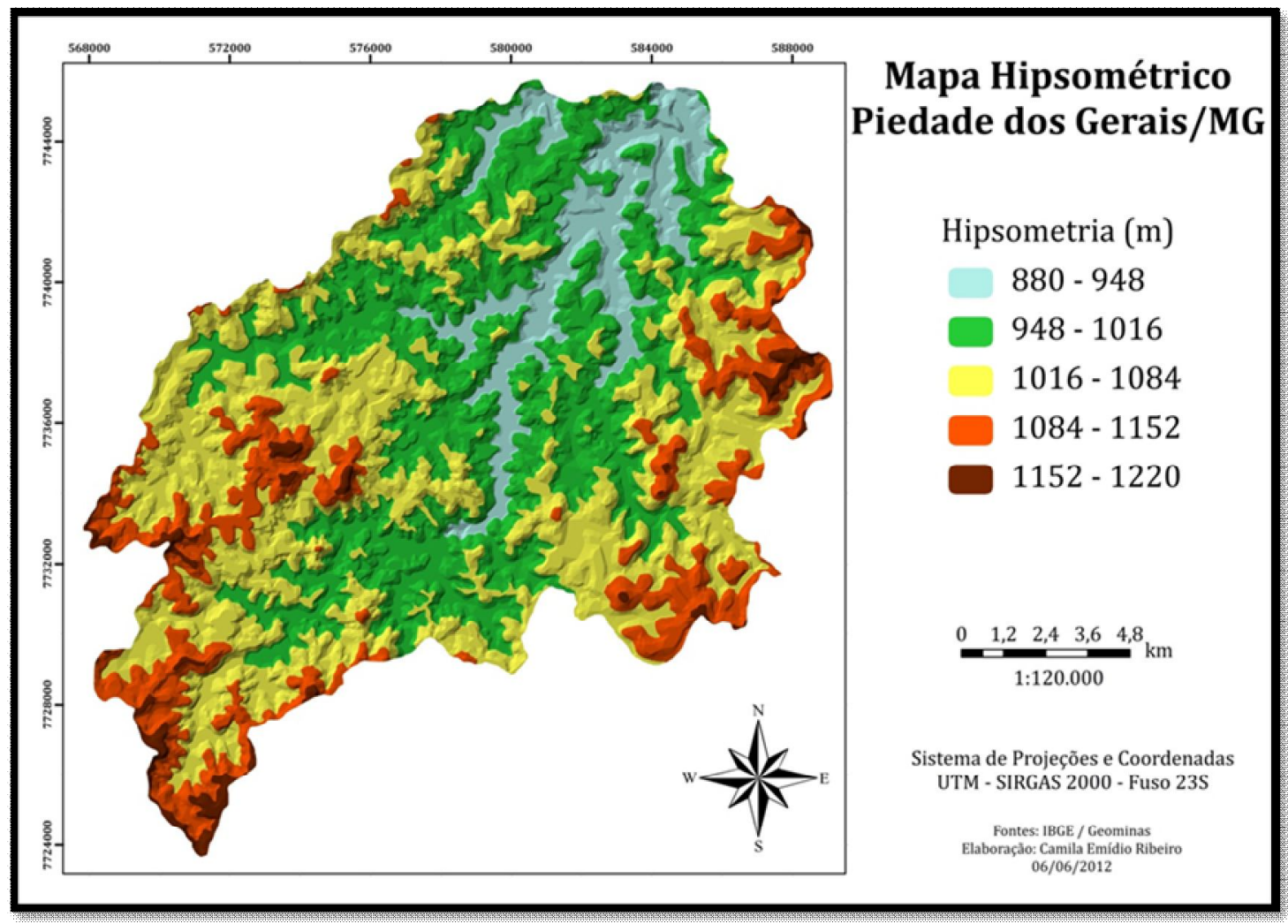

Figura 7 - Mapa hipsométrico do município de Piedade dos Gerais/MG.

\section{MAPEAmento do Uso e Ocupação do}

\section{Solo de Piedade dos Gerais/MG}

O Mapa de Uso e Ocupação do Solo é apresentado na Figura 8. Foram relacionadas 7 classes de diferentes tipos de uso, conforme Tabela 4.

Pode-se verificar que há a predominância do uso da terra para a agropecuária (agricultura e pastagem), representando $66,17 \%$ e, juntamente com a terra em preparo, essa classe passa a abranger $73,35 \%$ do uso total, corroborando o Censo Agropecuário de 2006. No entanto, segundo dados do IBGE, grande parte é destinada à pastagem.

\section{Tabela 4}

Classes de uso do solo e suas respectivas porcentagens que ocupam em relação à área total.

\begin{tabular}{|l|c|}
\hline \multicolumn{1}{|c|}{ CLASSE } & $\begin{array}{c}\text { \% da Área do Município } \\
\text { de 259,638 } \mathbf{~ k m}^{2}\end{array}$ \\
\hline $\begin{array}{l}\text { Agropecuária (áreas de } \\
\text { agricultura e pastagem) }\end{array}$ & 66,17 \\
\hline Silvicultura - eucalipto & 2,47 \\
\hline Urbanização & 2,88 \\
\hline $\begin{array}{l}\text { Terra em preparo para } \\
\text { agropecuária }\end{array}$ & 7,18 \\
\hline Solo exposto & 2,22 \\
\hline Vegetação densa & 18,44 \\
\hline Água & 0,65 \\
\hline
\end{tabular}




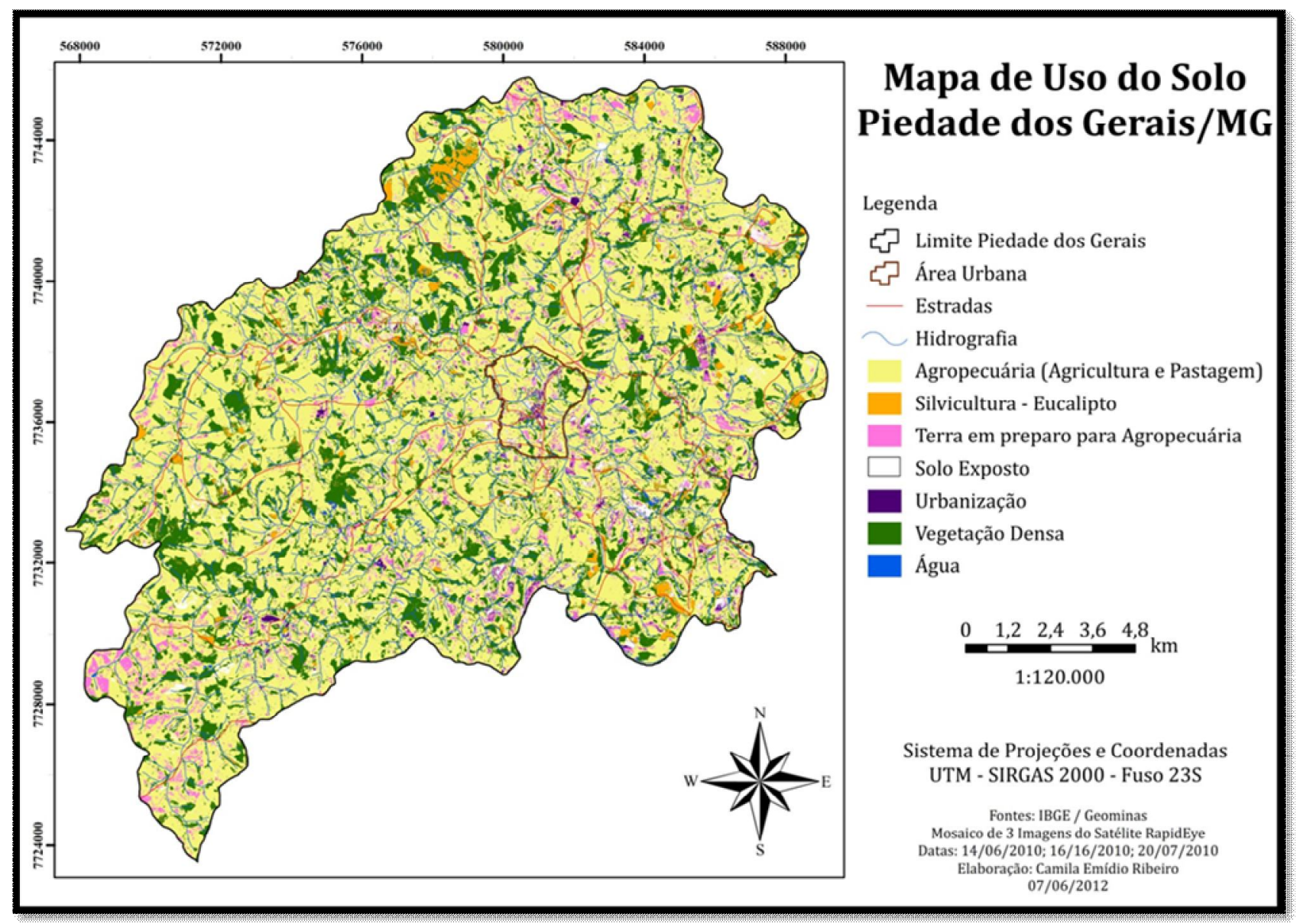

Figura 8 - Mapa de Uso e Ocupação do Solo do município de Piedade dos Gerais.

A vegetação densa segue com $18,44 \%$; a plantação de Eucalipto segue com 2,47\%; o solo exposto (solos degradados ou sem uso) segue com 2,22\%; a urbanização (o centro urbano, as residências em área rural e as estradas) segue com $2,88 \%$ e a água segue com apenas $0,65 \%$. Porém deve-se ressaltar que, devido ao fato de os rios do município não possuírem grandes extensões e largura, algumas regiões ficaram encobertas, dificultando sua identificação ao realizar-se a classificação supervisionada.

Apesar da grande extensão rural existente de áreas destinadas à agropecuária no município, segundo dados do IBGE, o PIB de maior influência é o do setor de comércios, seguido pelo setor agropecuário. Este fato revela que, apesar das vastas áreas destinadas a esse uso, ele confere ao município um menor retorno econômico, o que gera o questionamento sobre a real necessidade de destinar tantas terras para uma atividade pouco rentável e insustentável ambientalmente.

\section{CONFRONTO dO USO do SOLO COM AS Áreas de Preservação Permanente}

Através da elaboração dos mapas de Uso e Ocupação do Solo e das Áreas de Preservação Permanente (Topos de Morro e Cursos D’água), foi possível realizar o confronto analisando o conflito de Usos da Terra dentro de APP's do município de Piedade dos Gerais e gerando um mapa (Figura 9). Os resultados são apresentados na Tabela 5. 
Tabela 5

Resultados gerados a partir do confronto analisado feito através do conflito existente entre os Usos da Terra dentro das APP's do município de Piedade dos Gerais/MG.

\begin{tabular}{|l|c|c|c|}
\hline \multicolumn{1}{|c|}{ CLASSE } & $\begin{array}{c}\text { Uso do Solo de Piedade } \\
\text { dos Gerais dentro das } \\
\text { APP's cursos d'água }\end{array}$ & $\begin{array}{c}\text { Uso do Solo de Piedade } \\
\text { dos Gerais dentro das } \\
\text { APP's topo de morros }\end{array}$ & $\begin{array}{c}\text { Uso do Solo de Piedade } \\
\text { dos Gerais dentro das } \\
\text { APP's totais }\end{array}$ \\
\hline $\begin{array}{l}\text { Agropecuária (áreas de } \\
\text { agricultura e pastagem) }\end{array}$ & $65,68 \%$ & $65,30 \%$ & $65,14 \%$ \\
\hline Silvicultura - eucalipto & $1,31 \%$ & $3,97 \%$ & $2,99 \%$ \\
\hline Urbanização & $3,04 \%$ & $2,41 \%$ & $2,65 \%$ \\
\hline $\begin{array}{l}\text { Terra em preparo para } \\
\text { agropecuária }\end{array}$ & $1,90 \%$ & $6,95 \%$ & $6,09 \%$ \\
\hline Solo exposto & $1,51 \%$ & $2,14 \%$ & $1,86 \%$ \\
\hline Vegetação densa & $22,49 \%$ & $18,91 \%$ & $20,63 \%$ \\
\hline Água & $1,08 \%$ & $0,33 \%$ & $0,65 \%$ \\
\hline
\end{tabular}

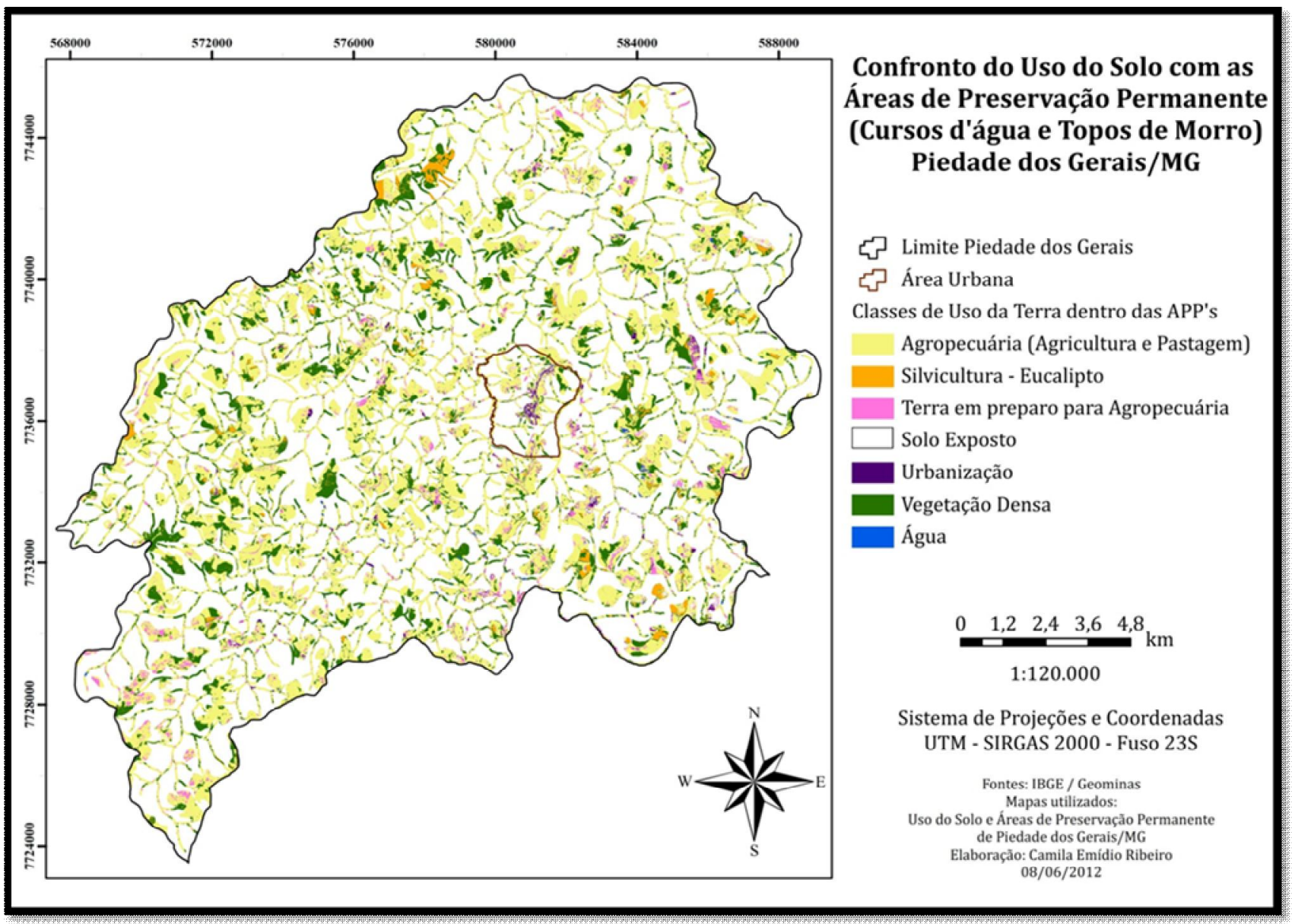

Figura 9 - Mapa do confronto entre o uso do solo e as Áreas de Preservação Permanente do município de Piedade dos Gerais/MG. 
Conforme resultados, as Áreas de Preservação Permanente estão, em sua maior parte, sendo utilizadas para fins de agropecuária, principalmente para áreas de pastagem, com $65,14 \%$ e, quando somadas às áreas de preparo da terra, totalizam $71,23 \%$ de uso. As APP's cursos d'água e de topos de morro, separadamente, também seguem esse mesmo padrão, com $65,68 \%(67,58 \%$ somada a terra em preparo) e $65,30 \%$ (72,25\% somada a terra em preparo) respectivamente, de uso destinado à agropecuária, o que faz desses locais altamente susceptíveis a danos ambientais.

Esse tipo de uso da terra proporciona uma maior exposição do solo, o que acelera o processo de degradação e de erosão. Em regiões de topos de morro que estejam expostas, a velocidade do escoamento superficial aumenta de acordo com a declividade do terreno e, consequentemente, o risco de danos ambientais e sociais se torna iminente.

Segundo mapa de declividade do município de Piedade dos Gerais (Figura 4), apesar de a região não possuir uma declividade de $100 \%\left(45^{\circ}\right)$, em algumas áreas ela é bastante acentuada. Nesse sentido, a vegetação nativa se torna primordial para conter o escoamento acelerado de partículas, evitando o processo de degradação e erosão do solo, como, por exemplo, o surgimento de voçorocas.

Já em regiões de curso d'água, em áreas que não estejam com a vegetação ciliar preservada e intacta, como apresentado nos resultados deste estudo, há o risco de assoreamento de rios e nascentes. As chamadas matas ciliares são extremamente importantes no sentido de contribuírem como barreiras naturais, evitando o depósito acelerado de partículas nas calhas fluviais, para que não sejam sobrecarregadas e interrompam seu fluxo natural, causando sérios impactos ao ambiente e, consequentemente, à população. Os rios nessa região fazem parte de sub-bacias que desaguam na bacia do rio São Francisco. Um mau uso regional pode causar consequências negativas não apenas locais, mas também em nível nacional.

A substituição de florestas nativas por florestas plantadas de eucalipto surge no cenário municipal, sendo que seu uso está em 2,99\% dentro das APP's totais, $1,31 \%$ nas APP's cursos d'água e 3,97\% nas APP's topos de morro. A retirada dessa espécie em áreas de preservação permanente deve ser feita com urgência, visto que são espécies exóticas, altamente agressivas e que eliminam por competição as espécies nativas, prejudicando a permanência da biodiversidade local. Portanto, jamais deve ser indicado o seu plantio em APP's.

Os outros usos apresentados são o de urbanização, com $2,65 \%$ de áreas presentes dentro de APP's totais, terras em preparo para agricultura com 6,09\% e solos expostos com $1,86 \%$.

As áreas de vegetação densa estão presentes em apenas 20,63\% das Áreas de Preservação Permanente totais do município. Nas APP's cursos d'água correspondem a 22,49\% e nas APP's topos de morro correspondem a $18,91 \%$ da área. Esse é um dado alarmante diante da importância e necessidade de vegetação nessas regiões, evidenciando não estar em consonância com as legislações municipal, estadual e federal.

De acordo com a Lei Orgânica Municipal de Piedade dos Gerais/MG, de 12 de maio de 1990, fica evidente, após os resultados obtidos, que a atribuição de preservar o meio ambiente cabível ao poder público e à população não está sendo cumprida. Isso pode ser percebido por meio de parte do capítulo da Lei em que se trata sobre o Meio Ambiente:

\section{CAPÍTULO III} DO MEIO AMBIENTE E DO TURISMO

Art. 154-A. O Município providenciará, com a participação efetiva da população, a preservação, conservação, defesa, recuperação e melhoria do 
meio ambiente natural, artificial e do trabalho, atendidas as peculiaridades regionais e locais, em harmonia com 0 desenvolvimento social e econômico, para assegurar a todos os cidadãos o direito ao meio ambiente ecologicamente saudável e equilibrado.

$\S 1$ 을 a assegurar a efetividade desse direito, incumbe ao poder público, através de órgãos próprios e do apoio à iniciativa popular, proteger o meio ambiente, preservar os recursos naturais, ordenando o seu uso e exploração, e resguardar - equilíbrio do sistema ecológico, sem discriminação de indivíduos ou regiões, através de política de proteção do meio ambiente, definida por lei.

§ 2o Incumbe ainda ao poder público:

(...)

III - definir espaços territoriais e seus componentes a serem especialmente protegidos, sendo a alteração e a supressão, permitidas somente através de lei, vedada qualquer utilização que comprometa a integridade dos atributos que justifiquem sua proteção;

(...)

VIII - distribuir equilibradamente a urbanização em seu território, ordenando o espaço territorial de forma a constituir paisagens biologicamente equilibradas;

(...)

XI - compatibilizar o desenvolvimento econômico e social do Município, com a preservação, o melhoramento e a estabilidade do meio ambiente, resguardando sua capacidade de renovação e a melhoria da qualidade de vida;

XII - prevenir e reprimir a degradação do meio ambiente e promover a responsabilidade dos autores de condutas e atividades lesivas;

(...)

XIV - proibir os desmatamentos indiscriminados, principalmente os das matas ciliares;

XV - combater a erosão e promover, na forma da lei, o planejamento do solo agrícola independentemente de divisas ou limites de propriedades;

$(\ldots)$

XIX - implantar banco de dados sobre o meio ambiente da região;

$X X$ - exigir a utilização de práticas conservacionistas que assegurem a potencialidade produtiva do solo;

(..)

XXIII - promover e manter o inventário e o mapeamento da cobertura vegetal nativa e dos rios, córregos e riachos, componentes das bacias hidrográficas do Município, visando à adoção de medidas especiais de proteção, bem como promover o reflorestamento, em especial, das margens dos rios, visando a sua perenidade.

(...)

$\S 3^{\circ}$ Aquele que explorar recursos minerais fica obrigado a recuperar o meio ambiente degradado, de acordo com solução técnica exigida pelo órgão público competente, na forma da lei:

I - a lei definirá os critérios, os métodos de recuperação, bem como as penalidades aos infratores, sem prejuízo da obrigação de reparar os danos causados;

II - a lei definirá os critérios de recuperação da vegetação em áreas urbanas.

$\S 4^{\circ}$ Nas condutas e atividades consideradas lesivas ao meio ambiente, ficarão sujeitos os infratores, pessoas físicas ou jurídicas, às sanções penais e administrativas.

(...)

\section{CONSIDERAÇõES FinAIS}

A utilização da terra por ações antrópicas vem sendo feita, ao longo principalmente da última década, de forma desordenada e sem planejamento prévio, procedimento que evitaria danos ao ambiente. A crise ambiental se concretizou como consequência da exploração indiscriminada dos recursos naturais que não podem ser consideradas fontes inesgotáveis de consumo e matéria prima. Através dos resultados encontrados neste estudo, pode-se confirmar essas afirmações.

De acordo com os mapeamentos propostos por este estudo, foi possível concluir que o município de Piedade dos Gerais/MG tem suas terras exploradas pela agropecuária de maneira intensa. É provável que esse fato seja proveniente, segundo caracterização histórica de Piedade dos Gerais, da intensa exploração das terras em busca do ouro e de matérias primas na época da colonização do Brasil e de um pensamento do passado em que eram considerados ricos e poderosos aqueles que possuíam grandes latifúndios.

A partir da análise do mapa de conflito do Uso da Terra no município dentro das Áreas de Preservação Permanente de Cursos D'água e Topos de Morro, 
nota-se também a predominância do uso da terra para a agropecuária (agricultura e pastagem). Um resultado negativo frente à importância de se manter nessas áreas as vegetações nativas intactas a fim de se evitar o escoamento superficial acelerado, causando e agravando o processo de erosão e o assoreamento de rios.

Mesmo com a presença de uma Área de Proteção Ambiental na região, a APA Municipal Vale do Rio Macaúbas, de acordo com a caracterização ambiental, o município não está em consonância com a legislação ambiental vigente e com sua própria Lei Orgânica. Isso ocorre por não manter preservadas as APP's e por dispor de grandes extensões de terra para a agropecuária, principalmente para áreas de pastagem, sem a necessidade, visto que seu PIB principal é mantido pelo setor de serviços, segundo sua caracterização socioeconômica.

O uso de geotecnologias se mostrou eficiente para a classificação e para o levantamento de Uso do solo neste trabalho, assim como o mapeamento das Áreas de Preservação Permanente e o conflito existente de usos da terra dentro dessas regiões. Sendo assim, se tornam ferramentas aliadas o estabelecimento de novos estudos e levantamentos que auxiliem o poder público na tomada de decisões.

Com a apresentação desses resultados, aconselhase um estudo sobre o Uso e Ocupação do Solo em áreas de Reserva Legal, que o município promova a recuperação das áreas degradadas, especialmente em APP's, para que estas mantenham suas funções ecológicas. Ainda é recomendável que o município elabore, juntamente com a população, técnicas sustentáveis de pecuária e fiscalize tais ações, de modo eficaz, para que haja cumprimento da legislação e que novas áreas não sejam degradadas. Nesse contexto, além de ficar em conformidade com as legislações, promoverá um ambiente saudável e equilibrado, rico em biodiversidade para as gerações presentes e futuras de todos os seres e espécies existentes.

\section{REFERÊNCIAS}

ASSIS, J. G. Piedade... o recanto das Gerais. Contagem, 2001. 136p.

BARBOSA, Í. S.; ANDRADE, L. A.; ALMEIDA, J. A. P. Evolução da cobertura vegetal e uso agrícola do solo no município de Lagoa Seca, PB. Rev. bras. eng. agríc. ambient. [online]. 2009, vol.13, n.5, pp. 615-622. Disponível em: <http://dx.doi.org/10.1590/S1415-

43662009000500015>. Acesso em: 05 set. 2011.

BRASIL. Lei $n^{\circ} 4.771$, de 15 de Setembro de 1965. Código Florestal Brasileiro.

BRASIL. Lei no 12.651, de 25 de maio de 2012. Novo Código Florestal Brasileiro.

BRASIL, SNUC. Lei no 9.985 , de 18 de julho de 2000. Institui o Sistema Nacional de Unidades de Conservação.
BRASIL. Resolução do Conselho Nacional do Meio Ambiente - CONAMA $n^{\circ} 303$, de 20 de Março de 2002. Dispõe sobre as áreas de preservação permanente.

BRITO, J. L. S.; PRUDENTE, T. D. Mapeamento do uso da terra e cobertura vegetal natural do município de Uberlândia - MG, utilizando imagens CCD/CBERSD 2. Caminhos de Geografia, Uberlândia, v. 13, n. 15, p. 144-153, 2005. Disponível em:

<http://www.seer.ufu.br/index.php/caminhosdegeogra fia/article/viewFile/10208/6077>. Acesso em: 05 set. 2011.

CÂMARA, G.; MEDEIROS, J. S. Geoprocessamento para projetos ambientais. Apostila. São José dos Campos: INPE, 2001. 147p. Disponível em: $<$ http://mtcm12.sid.inpe.br/col/sid.inpe.br/sergio/2004/04.19.15. 
08/doc/cap10-aplicacoesambientais.pdf>.

Acesso em: 05 set. 2011.

CARVALHO, G. A. Análise Espacial Urbano-SócioAmbiental como subsídio ao planejamento territorial do município de Sabará-MG com o apoio do geoprocessamento. Dissertação (Mestrado) em Análise Ambiental - Universidade Federal de Minas Gerais, UFMG, Brasil 2010. 133 p. Disponível em: <http://hdl.handle.net/1843/MPBB-83PFA2>. Acesso em: 03 set. 2011.

CASTRO JÚNIOR, R. M. (Coord). UFES UNIVERSIDADE FEDERAL DO ESPÍRITO SANTO. Laboratório de Topografia e Cartografia. Fundamentos de Geoprocessamento, [2011?]. Disponível em:

<http://www.ltc.ufes.br/geomaticsce/Modulo\%20Geo processamento.pdf/>. Acesso em: 06 set. 2011.

COSTA, T. C. C.; SOUZA, M. G.; BRITES, R. S. Delimitação e caracterização de áreas de preservação permanente por meio de um Sistema de Informações Geográficas (SIG). Revista Árvore.Viçosa - MG, v.20, n.1, p.129 - 135, 1996.

DAINESE, R. C. Sensoriamento Remoto e Geoprocessamento aplicado ao estudo temporal do uso da terra e na comparação entre classificação não-supervisionada e análise visual. Dissertação (Mestrado) - Universidade Estadual Paulista (UNESP) - Faculdade de Ciências Agronômicas, Câmpus de Botucatu, Fevereiro de 2001. 185 p. Disponível em:

<http://www.athena.biblioteca.unesp.br/exlibris/bd/bla /33004064021P7/2001/dainese_rc_me_botfca.pdf>.

Acesso em: 20 out. 2011.

FLORENZANO, T. G. Imagens de satélite para estudos ambientais. São Paulo: Oficina de Textos, 2002. $97 \mathrm{p}$.

IBGE CIDADES. 2010. Piedade dos Gerais, Minas Gerais - MG, Histórico. Disponível em: <http://www.ibge.gov.br/cidadesat/link.php?codmun= 315040>. Acesso em: 23 out. 2011.

IBGE - Instituto Brasileiro de Geografia e Estatística. Geociências (bases mapas temáticos.). Disponível em:

<http://downloads.ibge.gov.br/downloads_geociencia s.htm >. Acesso em: 23 out. 2011.

IBGE - Instituto Brasileiro de Geografia e Estatística. Censo 2010. Disponível em: <http://www.ibge.gov.br/home/estatistica/populacao/c enso2010/tabelas_pdf/Minas_gerais.p>. Acesso em: 23 out. 2011
IBGE - Instituto Brasileiro de Geografia e Estatística. Manual Técnico de Uso da Terra. $2^{\mathrm{a}}$ edição, Rio de Janeiro, 2006. Disponível em: <http://www.ibge.gov.br/home/geociencias/recursosn aturais/usodaterra/manual_usodaterra.shtm>.

Acesso em: 05 set. 2011.

MARQUES, L. S. Plano De Caracterização Da Área De Proteção Ambiental Vale Do Rio Macaúbas. Piedade dos Gerais, março de 2011.

MATSON, P. A. et al. Agricultural intensification and ecosystem properties. Science 277: 504 - 509, 1997.

MINAS GERAIS. Lei no 14.309 , de 19 de junho de 2002. Dispõe sobre as Políticas Florestal e de Proteção à Biodiversidade no Estado de Minas Gerais.

PACHÊCO, A. P.; RIBAS, N. S. Sensoriamento Remoto Aplicado ao Uso da Terra. Geodésia, 1998. Disponível em: <http://geodesia.ufsc.br/Geodesia online/arquivo/1998/04/PACHECO.HTM> Acesso em: 06 set. 2011.

PELUZIO, T. M. O.; SANTOS, A. R.; FIELDER, N. C. (Orgs). Mapeamento de áreas de preservação permanente no ArcGIS 9.3. Alegre: CAUFES, 2010, $58 \mathrm{p}$.

PIEDADE DOS GERAIS. Lei Orgânica Municipal de Piedade dos Gerais/MG, de 12 de maio de 1990.

PIEDADE DOS GERAIS. Lei ${ }^{\circ} 721$ de 26 de abril de 2011. Estabelece Zoneamento Ambiental EcológicoEconômico para a Área de Proteção Ambiental Municipal Vale do Rio Macaúbas.

RIBEIRO, C. A. A. S. et al. O desafio da delimitação de áreas de preservação permanente. Revista Árvore, v.29, n.2, p.203-212, 2005.

RODRIGUES, M. Geoprocessamento: um retrato atual. Revista Fator GIS. Curitiba, 1993.

SIGNORI, A. et al. Caracterização ambiental dos usos e ocupação da terra como base para 0 planejamento ambiental do município de Boa Vista das Missões - RS. XV Simpósio Brasileiro de Sensoriamento Remoto, 2011, Curitiba. Anais do XV Simpósio Brasileiro de Sensoriamento Remoto, 2011. Disponível em:

<http://marte.dpi.inpe.br/rep/3ERPFQRTRW/3A6HQ ES?mirror=urlib.net/www/2011/03.29.20.55\&metadat arepository=>. Acesso em: 13 nov. 2011.

SILVA, T. C. Demanda de instrumentos de gestão ambiental: zoneamento ambiental. Brasília/DF: Instituto Brasileiro de Meio Ambiente e dos Recursos Naturais Renováveis - IBAMA, 1997. 33p. 
XAVIER-DA-SILVA, J.; ZAIDAN, R. T. Geoprocessamento aplicado ao zoneamento de áreas com necessidade de proteção: o caso do Parque Estadual do Ibitipoca - MG. In: XAVIER-DASILVA, J.; ZAIDAN, R. T. (Org.). Geoprocessamento e Análise Ambiental: aplicações. 1 ed. Rio de Janeiro: Bertrand Brasil, 2004a, v. 1, p. 31-65.
XAVIER-DA-SILVA, J.; ZAIDAN, R. T Geoprocessamento e Análise Ambiental: aplicações. Rio de Janeiro: Bertrand Brasil, 2004b. $363 \mathrm{p}$. 